\title{
FRONTEIRAS NA FRONTEIRA: a trajetória dos migrantes brasiguaios e a influência econômico-jurídico-político-ideológica dos Estados nacionais (BR e PY), a origem do aluno brasiguaio
}

\section{FRONTIERS AT THE FRONTIER: the trajectory of braziguayans migrants and the ideological-political-economic-judicial influence of the national states (BR and PY), the origin of the braziguayan student}

\author{
Margarete Frasson \\ Mestre em Geografia, Universidade Estadual do Oeste do Paraná \\ Campus de Francisco Beltrão \\ marga.sti@hotmail.com \\ Marli Terezinha Szumilo Schlosser \\ Doutora em Geografia, Universidade Estadual do Oeste do Paraná \\ Campus de Marechal Cândido Rondon \\ marlisch20@hotmail.com
}

Artigo recebido para revisão em 23/02/2015 e aceito para publicação em 13/04/2015

\begin{abstract}
Resumo
Nesse texto coloca-se em relevo as relações e inter-relações entre Brasil e Paraguai analisadas na Região da Tríplice Fronteira (BR, PY e AR), em sua base material e normativa, formada por diferentes territórios, que permitiu e permite a fluidez de movimentação dos brasiguaios na fronteira. Neste caso, a fronteira é entendida como lugar de relações e inter-relações políticas, econômicas e ideológicas entre territórios. Com base nesse percurso teórico, analisam-se como tais questões estão presentes e permeiam a realidade vivida pelas famílias brasiguaias que buscam se territorializarem na fronteira. A análise dos prontuários dos alunos, deixa evidente a movimentação desse grupo de migrantes na fronteira entre Brasil e Paraguai. Por meio do relato oral obteve-se o registro da experiência vivencial, informações da história de vida e da identidade das famílias brasiguaias com filhos matriculados em duas escolas públicas ${ }^{1}$ do Município de Santa Terezinha de Itaipu/BR, em 2012. Isso permitiu realizar uma leitura cruzada da história, numa visão geográfica. Tornou possível perceber a influência exercida pelo poder dos Estados Nacionais, em sua dinâmica econômico-jurídico-político-ideológica e populacional. Conclui-se que o sujeito brasiguaio, presente nas escolas públicas dessa fronteira, teve origem pelas formas de exclusão social que envolve essas relações de poder.
\end{abstract}

Palavras-chave: história oral; brasiguaio; Tríplice Fronteira; relações de poder;

\begin{abstract}
In this text it's put into relief the relationships and interrelationships between Brazil and Paraguay analyzed in the TriBorder Region (BR, PL, AR), in its material base and rules, formed by different territories, that allowed and allows the fluidity of the braziguayans movement at the frontier. In this case, the frontier is understood as a place of relationships and political, economic and ideological interrelationships between territories. Based on this theoretical route, issues that are present and permeate the reality experienced by braziguayan families seeking to settle down on the frontier are analyzed. The analysis of medical records of students, makes evident the movement of this group of migrants on the border between Brazil and Paraguay. Through the oral report it was obtained the registration of the living experience, information like the life story and identity of braziguayan families with children enrolled in two public schools in the municipality of Santa Terezinha de Itaipu / BR in 2012. This allowed performing a cross-reading of this story, a geographical vision. It made possible to notice the influence of the nation states power in their ideological-politicaleconomic-judicial and population dynamics. We conclude that the braziguayan person present in this frontier public schools, had its origin by the forms of social exclusion that involves these power relations.
\end{abstract}

Keywords: Oral story; braziguayan; Triple Frontier; power relations;

\footnotetext{
${ }^{1}$ Escola Municipal Monteiro Lobato e Escola Municipal Olímpio Sprícigo.
} 


\section{INTRODUÇÃO}

A dinâmica econômico-jurídico-político-ideológica na Tríplice Fronteira, Brasil (BR), Paraguai (PY) e Argentina (AR), especificamente entre os Estados nacionais Brasil e Paraguai (Figura 1), sua base material e normativa, permitiu e permite que os movimentos populacionais, neste caso específico, o movimento dos brasiguaios faça parte de uma realidade concreta e complexa. Essa complexidade e concretude tem uma gênese, pois não é obra pura do acaso nem da imaginação, embora acaso e imaginação façam parte da trajetória dos seres humanos no mundo.

Esta pesquisa ${ }^{2}$ inicia-se ao identificar cento e trinta e três alunos com experiência de estudo no Paraguai e Brasil.(em quatro instituições de ensino públicas que atendem o Ensino Fundamental I, II e Ensino Médio, matriculados no ano letivo de 2012). A análise dos prontuários desses alunos, permitiu caracterizar o movimento desse grupo de migrantes na região da Tríplice Fronteira, especificamente entre Brasil e Paraguai. Por meio da história oral, dos pais dos alunos do Fundamenal I, obteve-se “[...] o registro da experiência vivencial, ou informações” (MEIHY, 1996, p. 65) da história de vida e da identidade das famílias dos 37 alunos brasiguaios, do segundo ao quarto ano do Fundamental I, inseridos em 20 turmas, entrevistando-se $38 \%{ }^{3}$ dos familiares dos alunos que vivenciaram a educação escolar dos dois lados da fronteira.

Para Thompson (2002, p. 208), "[...] recordar a própria vida é fundamental para nosso sentimento de identidade". E,

[...] é na fala, isto é, no processo de revisitar a memória que o entrevistado, muitas vezes, se descobre como sujeito da história, interpreta os encontros e desencontros que a vida apresenta nos seus múltiplos aspectos [...] (ALMEIDA, 2003, p. 38).

Ao agendar a data da entrevista, na ocasião esclarecia-se ao depoente que se tratava de uma pesquisa científica. Solicitava-se autorização para que o testemunho fosse utilizado como fonte de informação da pesquisa e se poderia ser gravado para transcrição posterior. Conhecedores desse detalhe, todos os entrevistados assinaram um termo, consentindo com o emprego de suas declarações como fonte de informação: “A finalidade de utilizar esta metodologia foi garantir, para ambos os lados, a seriedade da pesquisa científica" (HARACENKO, 2007, p. 63). A história oral destina-se à constatação da condição socioeconômica, à construção da trajetória desses migrantes ${ }^{4} \mathrm{e}$

\footnotetext{
${ }^{2}$ Faz parte da dissertação de mestrado: O aluno brasiguaio em movimento na Tríplice Fronteira, defendida em maio de 2014, junto a Universidade Estadual do Oeste do Paraná.

${ }^{3}$ Pretendia-se realizar a atividade de coleta de dados por meio do relato oral , com no mínimo 51\% das famílias, no entanto conseguiu-se entrevistar apenas 38\% delas. A análise dos prontuários desses alunos permitiu a complementação dos dados relevantes à pesquisa. O não ter atingido o número esperado atribui-se ao fato de a pesquisa ter ocorrido em janeiro (mês de férias pela possibilidade de flexibilização do tempo para as entrevistas). Nessa ocasião, várias famílias, por informações de vizinhos, haviam mudado de endereço, ou encontravam-se no Paraguai, sendo que algumas casas estavam fechadas e não se conseguiu contato.

4 “[...] um deslocamento de pessoas no espaço, e antes de mais nada, no espaço físico [...]. Mas o espaço de deslocamento não é apenas um espaço físico, ele é também um espaço qualificado em muitos sentidos, socialmente, economicamente, politicamente, culturalmente [...]" (SAYAD, 1998 p. 15).
} 
às razões que os motiva a esse deslocamento territorial. Utilizam-se apenas trechos do depoimento oral coletado como se faz em citações de autores.

A história oral, por estar “[...] atenta à inserção do indivíduo na sociedade [...]” (MEIHY, 1996, p. 66), apresentou-se como recurso para a compreensão dessa dinâmica,

[...] através das recordações de coisas vistas e ouvidas, a memória reconstitui, reinterpreta e preserva com as ideias, a aprendizagem, afeto e identidades, os sucessos, as experiências e as relações com as individualidades e coletividades do passado (MAROTTI; SANTOS, 2001, p. 197).

Considera-se que qualquer "[...] análise, para ser válida, não pode ser vazia da história concreta" (SANTOS, 2008a, p. 63). Inserir o relato da "história oral" em sua "[...] evidência dentro de um contexto mais amplo" (THOMPSON, 2002, p. 307) faz sentido, pois tempo, espaço, história e memória andam juntos.

\section{A FRONTEIRA:}

\section{TERRITÓRIO E PODER, RELAÇÕES E INTER-RELAÇÕES}

Os territórios delimitados em função dos diferentes critérios cabíveis (língua, hábitat, tamanho da terra, etc.) não coincidem perfeitamente. Isso, porém, não é tudo: as diferentes escalas espaciais que se apresentam no espaço de fronteira trazem em si uma infinidade de ações e de determinações que podem fazer parte da dinâmica da fronteira. Esse contexto faz o espaço fronteiriço apresentar-se à pessoa ora como local, ora como nacional, ora como internacional, dependendo das determinações a que ela está sujeita. Isso faz a fronteira, para os que vivem da força do trabalho, constituir-se em limite ou em possibilidade, ou as duas coisas, em lados diferentes da fronteira.

Esclarecer as relações existentes entre pessoas mediadas pelas bases e estruturas de materialização da sociedade no espaço permite entrever as transformações existenciais e espaciais, pois o jogo de forças que atuam nesse espaço fronteiriço é imperceptível ao estender o olhar sobre a paisagem: "o poder se manifesta por ocasião da relação" (RAFFESTIN, 2011, p. 47). Por isso, essas forças se fazem presentes no processo de relações e inter-relações que ocorrem nas diferentes escalas de poder, sendo percebidas pela pressão que exercem sobre o sujeito no lugar. Dessa forma, “o território não é menos indispensável, uma vez que é a cena do poder e o lugar de todas as relações [...]" (RAFFESTIN, 2011, p. 52). Nesta perspectiva, o território, o limite e a fronteira se 
estabelecem no espaço da Tríplice Fronteira (Representação 1$)^{5}$ determinando o externo e o interno a cada um dos territórios.

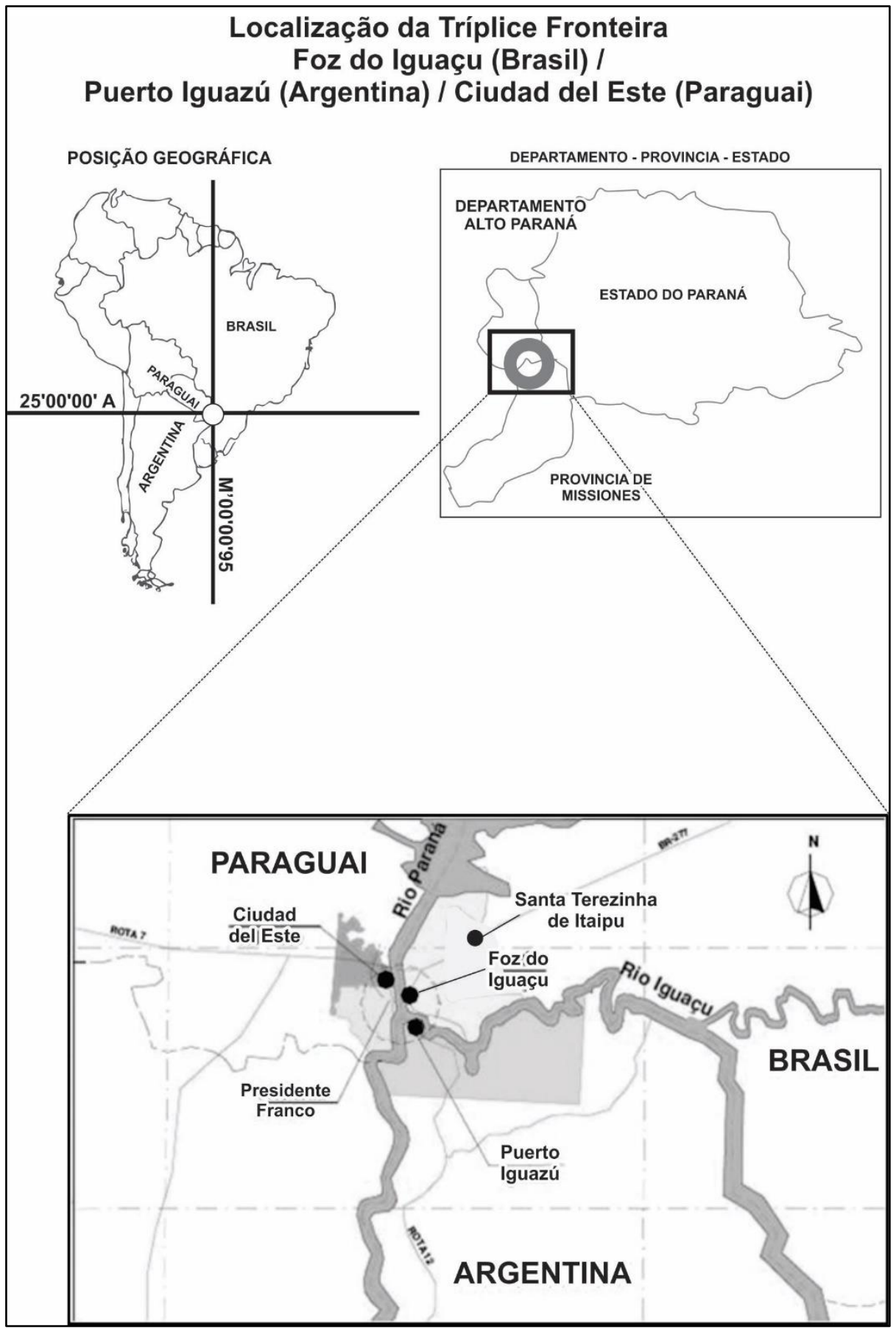

Representação 1 - Tríplice Fronteira, o território, o limite e a fronteira

Fonte: Fiscalização na Tríplice Fronteira ${ }^{6}$. Adaptada por Margarete Frasson

\footnotetext{
${ }^{5}$ A Representação mostra o espaço do território de três Nações (Brasil, Paraguai e Argentina) e, nesses territórios/espaços, em menor escala (Departamento, Estado e Província), localizam-se as cidades que constituem a área urbana da Tríplice Fronteira, com evidência de seus limites naturais, os rios Iguaçu e Paraná, que se constituem em divisas entre os três países (BR, PY e AR). Encontra-se no espaço fronteiriço o Município de Santa Terezinha de Itaipu, unidade administrativa mais próxima da Tríplice Fronteira, do lado brasileiro, espaço onde localizam-se as escolas, ponto de partida dessa pesquisa.

${ }^{6}$ Disponível em: <http://www.portalwagnermontes.com>. Acesso em: 3 set. 2013.
} 
A ação do poder determina a realidade do/no território. Nesse sentido, "a realidade do externo depende, todavia, do interno" (SANTOS, 2008, p. 105). Assim, as estratégias do poder interno normatizam as relações com o espaço externo. O espaço da Tríplice Fronteira trata-se de um lugar (AMARAL, 2010) fluido, multiforme e portador de atributos muitas vezes contraditórios, que divulgam as lutas entre suas distintas imagens e representações que a ele são atribuídas. Para Haesbaert (2011, p. 15), espaço como esse, permite "acionar mais de uma identidade territorial, dependendo das estratégias de poder que estiverem em jogo".

Essas estratégias de poder são denominadas por Hissa (2006, p. 35) de "fronteiras e limites são desenvolvidos para estabelecer domínios e demarcar territórios. [Que] Foram concebidos para insinuar precisão: a precisão que pede o poder”. Essa precisão vai determinar o fluxo na fronteira de bens, serviços e pessoas, no tempo e quantidade estabelecida pelo poder econômico que conta com o controle e precisão do poder político dos Estados nacionais para agir no espaço.

Saquet (2011, p. 40) chama esse fluxo de "[...] movimento objetivo e subjetivo, histórico e relacional de construção de territórios e territorialidades", de territorialização. Quando essa territorialização se dá em espaço transfronteiriços são denominadas de estratégias geopolíticas que mostra a fronteira em movimento.

Essa pesquisa ganha força e sentido por analisar que na fronteira "o verdadeiro poder se desloca para aquilo que é invisível em grande parte, quer se trate de informação política, quer econômica, quer social ou cultural" (FRAGA, 2011, p.71). E demonstra que "o poder [...] funciona em cadeia. [...] O poder funciona e se exerce em rede. [...] Nas suas malhas os indivíduos não só circulam, mas estão sempre em posição de exercer este poder e de sofrer sua ação [...] (FOUCAULT, 1982, P. 183). ${ }^{7}$

Dentro deste recorte teórico, será analisada a Tríplice Fronteira em sua teia formada pelas relações e inter-relações promovidas pela ação do poder. Pois, ao constituir-se como fato político, o espaço de fronteira permite aos governos dos Estados Nacionais legislarem de forma a definirem as medidas (limites) do movimento das pessoas, dos bens, dos produtos e dos serviços... por meio de acordos e tratados, geram sua integração ou a sua separação.

\section{DINÂMICA DA TRÍPLICE FRONTEIRA: CONSTRUÇÃO DO PROCESSO MIGRATÓRIO DE BRASILEIROS AO PARAGUAI}

O espaço da Tríplice Fronteira, demonstrado na Representação 1, ao longo de sua história tem passado por diversas reconfigurações, sendo que tal condição altera a sua dinâmica

\footnotetext{
${ }^{7}$ FOUCAULT, Michel. A Ordem do Discurso: aula inaugural no Collège de France, prounciada em 02 de dezembro de 1970; Tradução de Laura Fraga de Almeida Sampaio. São Paulo: Loyola, 2004.
} 
populacional pelas decisões políticas e econômicas tomadas pelos governos dos Estados nacionais (BR, PY e AR).

Nesse contexto, a área fronteiriça das Três Fronteiras em fins do século XIX e início do século XX, no oeste paranaense (Brasil), é alvo de conflitos nacionais entre civis e militares, com presença de tropas revolucionárias ${ }^{8}$ que lutam pelo poder político, até então marcado por acordos entre as oligarquias das províncias de São Paulo e Minas Gerais e o governo federal (Política do “Café com Leite") que já não agrada nem ao Rio Grande do Sul, nem a outros estados 9 do Brasil. Com “[...] a Revolução de 1930 e a criação do Estado Novo em 1937, as 'obrages" ${ }^{10}$ entram em decadência” (ZAAR, 1999, p. 17) por “[...] anulação das várias concessões de terras no Paraná, sobretudo pela inoperância e o não cumprimento de cláusulas contratuais. Retornam ao patrimônio do Estado 2.300.000 hectares de terra" (WESTPHALEN et al., 1968, p. 5), fato que “[...] abriu as portas ao povoamento com levas migratórias vindas do Estado do Rio Grande do Sul e em menor escala de Santa Catarina" (COLODEL, 1988, p. 40). As áreas de “[...] terras que passam a ser adquiridas pelas companhias colonizadoras, a partir da década de 1940, os territórios dos futuros municípios, teriam como primeira base geográfica as antigas "obrages" (COLODEL, 1988, p. 3). Esses municípios seriam habitados por migrantes com um histórico de vida marcado pela necessidade econômica. Empresas particulares, com apoio do governo, medeiam as transações. A administração do Paraná de 1932 a 1950 apresenta uma política econômica e social voltada à modernização do Estado (IPARDES, 2006). O Paraguai coloca em ação o Projeto Nacional de Marcha para o Leste, por meio de convenções políticas e econômicas,

[...] criou as condições materiais para a expansão da fronteira agrícola capitalista no Leste do Paraguai [...], a partir da segunda metade do século XX, foi transferindo-se do raio de ação argentino para a órbita de influência geoeconômica e cultural do Brasil (BÁRBARA, 2005, p. 335),

Ao assumir o governo em 1954, Stroessner pretende deixar o capitalismo em expansão chegar àquela Nação. Assim, em 1959,

[...] dá início ao processo de transformação do setor agropecuário, por meio de políticas direcionadas à colonização e à modernização da fronteira agrícola paraguaia [...]. A primeira etapa [...] baseou-se na distribuição de terras para militares e líderes do Partido Colorado, e na contratação de empresas colonizadoras brasileiras, norte-americanas, alemãs e japonesas para organizarem a colonização. Muitos agricultores paraguaios foram expulsos de suas terras nesse período (MARQUES, 2009, p. 69),

\footnotetext{
${ }^{8}$ Uma delas é a Coluna Prestes, que combateu as obrages por dois motivos: de um lado, a miséria dos trabalhadores e, de outro, as oligarquias enriquecidas à custa das riquezas nacionais.

9 COLODEL, José Augusto. Cinco Séculos de História. Disponível em: <www.unioeste.br/projetos/ oraculus/PMOP/ capitulos/Capitulo 01.pdf>. Acesso em: 25 jun. 2012.

${ }^{10}$ Propriedades e/ou exploração típica das regiões cobertas pela mata subtropical, em território argentino e paraguaio. Sua existência baseava-se no binômio mate-madeira.
} 
O processo de colonização com o objetivo de modernizar a agricultura no Paraguai expulsa de suas terras os pequenos agricultores devido ao desenvolvimento das atividades agrárias que não se apresentam convenientes para os propósitos econômicos do governo daquele país, o qual pretende fortalecer as relações políticas, econômicas e comerciais com Brasil, Argentina, Estados Unidos e Europa, onde busca o apoio externo para manter-se no poder e legitimar seu governo.

Na região Oeste do Paraná/BR, no período de 1950 a 1970,

[...] grande parte da colonização dessas terras foi realizada por companhias privadas, o que resultou na constituição de vários núcleos coloniais, alicerçados sob o sistema da pequena propriedade e da policultura (MACCARI, 1999, p. 50).

Essa colonização “[...] deu-se por migrantes com características específicas, origens geográficas definidas” (GREGORY, 2008, p. 176), descendentes de europeus, cujos antepassados

[...] emigraram da Europa pressionados pela expansão das relações capitalistas de produção que expropriou os camponeses e artesãos, que precisaram buscar no espaço mundial fontes de trabalho e de renda (GREGORY, 2008, p. 42).

Os descendentes desses europeus possuíam experiência em explorar a pequena propriedade, nutriam um sentimento de posse da terra e apresentavam estrutura familiar forte. Conforme mostra a Representação 2, localização geográfica do Departamento de Alto Paraná, a Marcha em Direção ao Leste "[...] visava ocupar a fronteira leste do país com camponeses paraguaios" (GONÇALVES, 2011, p. 4).

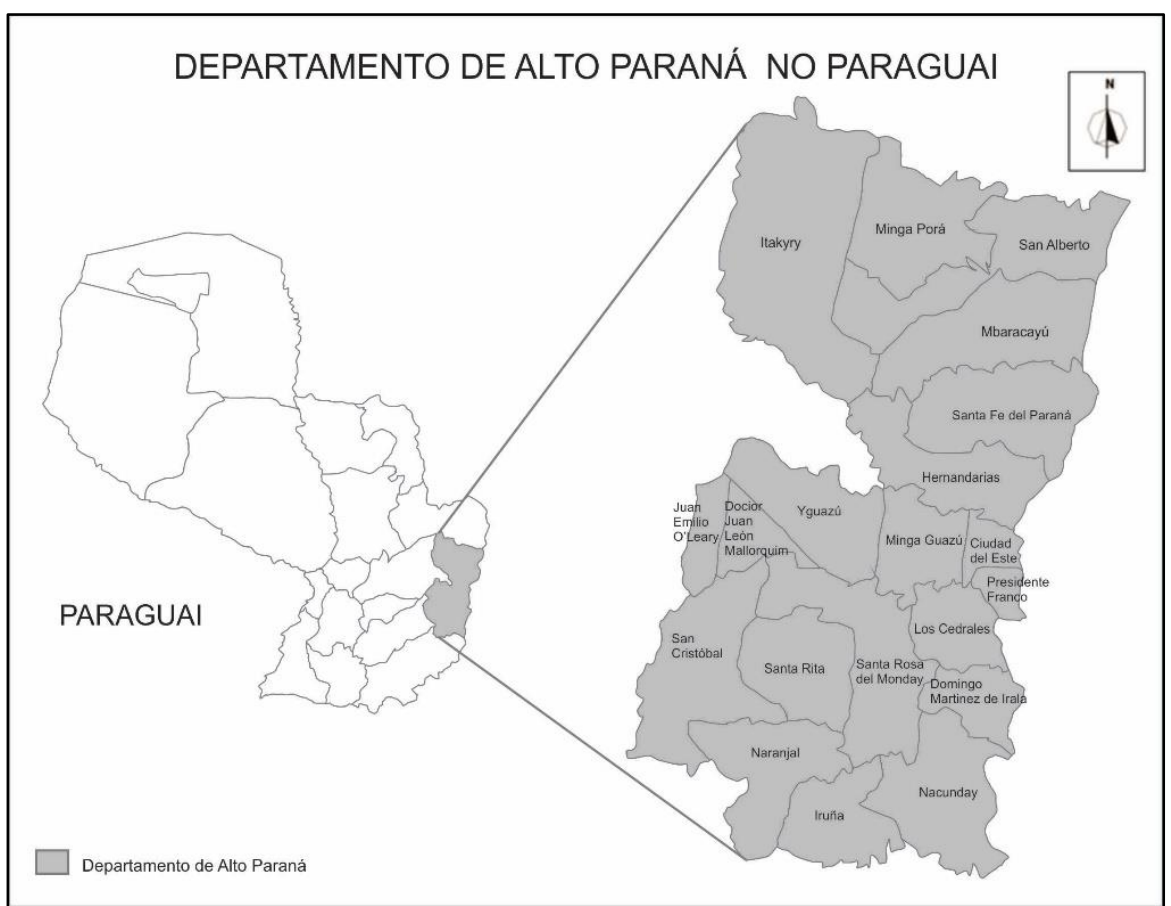

Representação 2 - Alto Paraná, Paraguai

Fonte:Alto Paraná (Departamento) ${ }^{11}$. Adaptada por Margarete Frasson, fev.2014

\footnotetext{
${ }^{11}$ Disponível em: <wikipedia.org/wiki/Alto_Paraná_(departamento)>. Acesso em: 4 set. 2013.
} 
No entanto, o governo militar de Stroessner desenvolveu uma política de incentivo à migração brasileira, “[...] dá-se inicialmente nas regiões norte e nordeste, do Brasil” (MARQUES, 2009, p. 69), porém,

[...] desprovidos da tradição de posse da terra, os novos imigrantes (negros, mulatos e cafuzos) trabalhavam na derrubada da mata e dedicavam-se à agricultura de sobrevivência e ao cultivo comercial da hortelã. Esses imigrantes experimentaram relativa estabilidade até o final dos anos 1960, quando Stroessner mudou sua política para o departamento de Alto Paraná. A segunda etapa do plano era atrair mão-de-obra brasileira oriunda do Sul do país. A ordem do Estado paraguaio era priorizar a mão-de-obra dos descendentes de alemães e convencê-los a ensinar 'aos preguiçosos paraguaios e a negrada brasileira' a trabalhar [...]. O afluxo massivo de colonos do Sul do Brasil para o Paraguai 'empurrou' os colonos do Norte e Nordeste para outras regiões daquele país [...] (MARQUES, 2009, p. 69).

O que existe por trás desse discurso é descaracterizar a identidade indígena-guarani que ali existe, em um processo semelhante ao que ocorreu no Brasil com o uso da colonização por migrantes alemães, "o clareamento da raça". O governo paraguaio quer inserir o país no comércio mundial, mas, acima de tudo, quer uma população branca como a da Europa e dos Estados Unidos, a qual é entendida, naquele momento, como sinônimo de desenvolvimento, lembrado pelos grandes ditadores que atuam no mundo à época que divulgaram a ideia de raça pura, superior, inteligente. Isso culmina como política estratégica com a finalidade de relacionar-se com os países vizinhos e obter vantagens econômicas, além de proteger a sua soberania e integridade territorial. Ao mesmo tempo, a colonização da Região Oeste paranaense pela pequena propriedade de subsistência foi utilizada pelo Estado como solução provisória para inserir a região na dinâmica do capitalismo, objetivando atender aos interesses dos grupos hegemônicos. Nesse sentido, observa-se a “[...] estreita relação entre o processo migratório e seu direcionamento com a penetração das relações capitalistas de produção" (GREGORY, 2008, p. 53).

Modernizar a economia paranaense também significava investir em eletricidade e rodovias, consideradas fundamentais para esse sistema no sentido de viabilizar as demais necessidades impostas à penetração do capital industrial. Para concretizar a modernização, o governo do Paraná firma convênio com os Estados Unidos e lança a campanha "Plante Soja. Use a Melhor Técnica e Ganhe Mais"12. Ao integrar "[...] o setor agrícola regional ao padrão tecnológico vigente no período, desagregou a antiga forma de produzir e, em consequência, as relações sociais entre a população residente no meio rural" (FLEISCHFRESSER, 1988, p. 7). Para Andrade (1979), o uso de máquinas, de adubos e de inseticidas amplia o poder de expansão das grandes culturas em detrimento das pequenas, exclui a força de trabalho no meio rural que era superior à distribuição de lotes de terra e expulsa as outras formas de trabalho, como a de diaristas, meeiros, parceiros e/ou arrendatários. Em contrapartida, facilita créditos às grandes empresas agrícolas que utilizam

\footnotetext{
${ }^{12}$ Fragmento (PARANÁ, Mensagem, 1970, apud IPARDES, 2006, p. 114).
} 
insumos de capital em substituição aos de trabalho, aumentando ainda mais o excedente de mão de obra.

Nesse sentido, empresas rurais apropriam-se da terra dos produtores familiares, aumentando os domínios empresariais. Provoca-se com isso o êxodo rural, que ocasionará problemas nas periferias das grandes cidades, produzindo uma massa de desempregados. Há o aumento da produção de mercadorias, pois o produtor rural utiliza produtos químicos e mecânicos para aumentar a produtividade. E o pequeno, sem o seu meio de produção, a terra, necessita comprar o que antes era produzido por ele.

A partir da década de 1950, Brasil (1964-1984) e Paraguai (1954-1989) vivem politicamente sob ditaduras militares, com o objetivo comum de desenvolver economicamente os Estados nacionais. Entre as metas brasileiras está a construção da maior usina hidroelétrica do mundo; entre as metas paraguaias está encontrar o caminho de contato com o exterior, tornando-se menos dependente da Argentina no que se refere ao comércio internacional, que então ocorria somente através da Bacia da Prata. Iniciam-se os acordos bilaterais entre os dois países. O governo paraguaio vê duas possibilidades bastante favoráveis, política e economicamente, de colocar o seu EstadoNação como produtor de grãos no mercado mundial, sendo pelo ingresso de agricultores brasileiros no país e pelo escoamento da produção através do corredor da Rodovia BR 277 ao Porto de Paranaguá, no estado do Paraná/BR. O governo brasileiro resolveria a desapropriação de terras que seriam ocupadas pelo Lago de Itaipu. Os agricultores desapropriados teriam como destino os estados do Mato Grosso, no Programa Nacional Brasileiro da Marcha para o Oeste, e o Paraguai, por incentivo do governo de Stroessner, oferecia terras “[...] aproximadamente dez vezes mais baratas que no Brasil” (SOUCHAUD, 2007, p. 122), no Programa Marcha para Leste.

Assim, do ponto de vista das relações internacionais,

[...] a hidrelétrica de Itaipu e a colonização agrícola ocorrem como efeito da aproximação dos dois países engajados na ocupação e integração de espaços periféricos de seu respectivo país: movimento convergente orientado em direção ao oeste do lado brasileiro e em direção ao leste do lado paraguaio (SOUCHAUD, 2011, p. 136)

Tais procedimentos confirmam-se por meio da história oral dos brasiguaios nesta pesquisa, pelas datas de mudança do Brasil para o Paraguai quando comparadas à época desses movimentos acima narrados. Quanto ao retorno ao Brasil, vários brasiguaios citam, entre os motivos, almejar futuro melhor para os filhos, destacando a escolaridade. O número de matrículas de alunos brasiguaios nas escolas públicas comprova o movimento que, nesta segunda década do século XXI, se faz em direção contrária. Neste sentido, "a fronteira deixa de ser linha, limite, finitude, o lugar da diferença [...]. Torna-se aberta, porosa, exemplo de integração e de aproximação" (SCHAFFER, 1995, p. 25 apud ALBUQUERQUE, 2010, p. 48). 
A fronteira como mecanismo do sistema capitalista, na segunda metade do século XX, age como um processo marcado pelo poder político dos Estados nacionais com repercussão direta sobre a população que vive no campo. Em 1963, o general Stroessner modifica o Estatuto Agrário de 1940, no Paraguai, permitindo a venda de terras a estrangeiros. No Brasil, permanece apenas no papel o Estatuto ${ }^{13}$ da Terra, promulgado em 1965. Aliado a isso, o uso da modernização agrícola e as leis trabalhistas fazem com que os proprietários de terras no Brasil evitem a permanência do trabalhador na propriedade para não originar vínculo empregatício. Soma-se ainda a esse fato, a organização da assistência creditícia e agronômica aos pequenos produtores que também não ocorre.

Assim, a fronteira é: "resultado da ação dos homens sobre o próprio espaço, intermediados pelos objetos, naturais e artificiais" (SANTOS, 2008b, p. 78), em que “[...] o modo de produção capitalista procura assegurar a fluidez dos elementos que utiliza, manipula e combina" (RAFFESTIN, 2011, p. 162). Nesse espaço, entre os elementos empregados pelo capitalismo, encontra-se o ser (elemento) humano.

\section{A BUSCA POR TERRITÓRIO NA FRONTEIRA: DE BRASILEIROS A BRASIGUAIOS}

Os fatos citados anteriormente provocam um grande contingente migratório para o Paraguai, inclusive dos que não têm recursos para a compra de terra, como é o caso da família da senhora Neiva Solane Shwendler, 35 anos, que foi para o Paraguai aos nove anos de idade, voltou ao Brasil há dois anos (em 2011) e relata como foi o cotidiano no Paraguai, entendendo-se que "os relatos cotidianos contam aquilo que, apesar de tudo, se pode aí fabricar e fazer. São feituras de espaço" (CERTEAU, 2008, p. 207), ou seja, feituras construídas e reconstruídas com dificuldade, economia e muito trabalho, abdicando até mesmo a atender as necessidades básicas do próprio corpo:

Fomos morar pro Paraguai porque a situação financeira não estava fácil. Na época em que era o cruzeiro. O pai vendeu tudo lá deu doze mil ou doze milhões de cruzeiros. Fomos pro Paraguai [...] Lá em Santa Catarina, futuro, futuro a gente jamais ia fazer, nós tinha aquele pedacinho de terra, pra progredir a gente não ia. [...] aqueles morros, pedras, um sacrifício para trabalhar lá. E lá, no Paraguai, aquelas terra bonita que a gente enxerga longe, some nas vistas. Aquela terra boa para trabalhar. Boa para plantar, produz bem. O sonho dele (pai) era ir embora para o Paraguai. Como ele conheceu um cara, em Santa Catarina, em Pratas, que tinha terra no Paraguai, fez amizade, e fomos para lá trabalhar nas terras dele. Trabalhamos quatro anos até conseguir comprar nosso primeiro pedacinho de terra. [...] A gente era pobre pra caramba. Comia mandioca três vezes por dia pra ter o que comer e matar a fome. [...] Era sofrido. Eu toquei de ir muito na roça, era tudo no muque. A gente catava raiz, machuquei minha coluna com quatorze anos. Era muito difícil. [...] A gente era

\footnotetext{
${ }^{13}$ Esse Estatuto previa uma política de intensificação e desenvolvimento da assistência à pequena propriedade e o cooperativismo que tornasse a pequena empresa agrícola economicamente viável.
} 
quatro irmãos e tinha um tio meu morando junto. Era como se fosse cinco filhos. Aí, nasceu mais um lá, era seis (SHWENDLER, Depoimento Oral ${ }^{14}$, jan. 2013).

Os depoimentos orais coletados, como esse (de dona Neiva Solane Shwendle), apresentam pessoas que não medem esforços quando se trata de trabalho e veem-no como a única alternativa para melhorar de vida. Economizam cada centavo para atingir os seus objetivos, porém a falta de perspectiva, as dificuldades para ganhar a vida em um solo improdutivo e a pobreza, associada à porosidade para o movimento dado pelas relações bilaterais entre os Estados nacionais, levaram muitas famílias a migrarem ao Paraguai. Isso é o que ocorre também com os pais de dona Marlice Ines Freitas Schinwelski, 36 anos de idade, ascendência alemã, nascida do Rio Grande do Sul, morando em Santa Terezinha há seis meses (2012):

Nasci no Rio Grande do Sul, fui para o Paraguai com cinco meses. Cresci no Paraguai. Morar no Brasil é uma experiência nova. O que sei é do Paraguai, daqui a gente está aprendendo agora. A gente trabalhou muito, na roça, a gente é da colônia. Trabalhei muito e estudei muito pouco. Só fiz o primeiro grado [...] Não tinha tempo para estudar, meus pais eram pobres, tinha que trabalhar para ajudar a sustentar a família. [...] Quanto a ir para o Paraguai, meu pai comentava que era para melhorar de vida. Eles foram só com a roupa do corpo e uma filha para criar.[...] Meu pai trabalhava com um cunhado. Depois, foi trabalhar com um alemão, onde fez o capitalzinho, que ele tem hoje. Trinta anos trabalhado para essa pessoa. Hoje, ele tem terra. Sempre trabalhamos na agricultura (SCHINWELSKI, Depoimento Oral, jan. 2013).

Esses migrantes deixam transparecer uma lacuna que trazem consigo e que, agora, projetam para vida dos filhos, a educação escolar, que não tiveram na infância/adolescência por estar fora das possibilidades econômicas ou pelo difícil acesso marcado pela distância entre a casa e a escola ou ainda por terem que se envolver nos trabalhos com a terra, uma vez que, no Paraguai, “[...] esses agricultores desmataram áreas imensas de selva, limparam os terrenos, construíram suas casas, tiveram seus filhos e produziram, durante anos [...] de arrendamento [...]” (SPRANDEL, 1998, p. 115) e sua mão de obra cumpre o papel na "limpeza dos terrenos", para, posteriormente, o capital fazer uso das inovações químicas e mecânicas em seu processo de produção (FLEISCHFRESSER, 1988). O sonho de tornarem-se proprietários de um pedaço de chão, de territorializarem-se, efetivamente, conduziu esses migrantes a fazerem determinadas opções, como economizar financeiramente, com isso adiando o atendimento às necessidades básicas. Nesse sentido, o seu cotidiano “[...] se dá em um quadro de vida onde as condições ambientais são ultrajadas, com agravos à saúde física [...]. Deixamos de entreter a natureza amiga e criamos a natureza hostil" (SANTOS, 2008b, p. 47).

Odenice Dionízio da Conceição, 42 anos, apresenta-se como integrante da fluidez provocada pelo capitalismo em expansão. Nasceu no Estado de Minas Gerais, a mãe nasceu em Pernambuco e

\footnotetext{
${ }^{14}$ Os depoimentos orais coletados, de pais dos alunos brasiguaios matriculados do $2^{\circ}$ ao $4^{\circ}$ ano em 2012 e inseridos neste texto, foram transcritos com leves correções para deixar a leitura de forma fluente e coesa aos olhos do leitor. Dos referidos depoimentos, foram utilizados apenas fragmentos, tendo sido escolhidos os que pudessem contribuir com o debate em torno da problemática abordada.
} 
o avô materno era do Pará. Os pais migraram para o Paraguai em 1972, quando ela ainda não havia completado um ano de vida. Casou com um paraguaio, teve os filhos naquele país e retornou ao Brasil há três anos. Ela morou 38 anos no Paraguai. De acordo com um fragmento de seu depoimento, relata:

\begin{abstract}
Nasci em Ribeirão Vermelho. Não conheço. Eu fui pequena para o Paraguai. Tinha oito (08) meses. Meus pais foram para lá. Eu me criei lá. Diversão, a gente não teve. De pequena, a gente se criou na roça, só trabalhando. Estudei um ano no Paraguai. Fiz o primeiro ano, primeiro grado. Passei de ano, daí a gente mudou. E já era mais caro, mais longe. Por isso, a gente não estudou mais. [...] Minha mãe nasceu em Pernambuco, em um lugar chamado Panelas de Miranda. Meu avô era de Belém do Pará. [...] No Paraguai, teve uma época que foi bom. Na época do sonho. Aí, foi dificultando. Foi que daí a gente veio para cá. Meu marido toma remédio controlado. Lá, não tem ajuda nenhuma. Quando se precisa de uma ambulância para levar para o hospital, não tem. Tem que pagar. O posto é longe. Aqui, o posto é perto. Fica mais fácil. Até mesmo para os paraguaios, lá, tá difícil. (O marido diz) 'A mi me gusta a la tierra. Me gusta para criar las niñas. Mas estoy enfermo. E lá tierra era muy chiquita'. [...] Falamos o espanhol. As crianças falavam o guarani e o meu marido também. [...] Tomo o tererê, mas não me faz falta. Agora, ele toma sempre. (O marido diz) 'Acá no consigo los remédios para colocar en el tererế'. Recebemos bolsa família e cesta básica, todo mês (CONCEIÇÃO, Depoimento Oral, jan. 2013).
\end{abstract}

A família da senhora Odenice Dionísio da Conceição vive o fenômeno da expropriação da terra, o qual faz com que o expropriado se transforme em proletário que vende a sua força de trabalho, tornando-se, portanto, uma parte da “[...] população desterrada, desterritorializada, como muitos brasileiros cuja vida é migrar" (GONÇALVES, 1984, p. 155-156), chegando ao ponto em que “[...] não são incluídos nem marginais, eles são excluídos” (SANTOS, 2008, p. 72), Assim, passam a sobreviver basicamente das políticas públicas, como é o caso da família de Odenice, que depende do sistema de saúde, da cesta básica e da bolsa escola. A fronteira, portanto, apresenta-se não apenas como marcos de delimitação fixados no território físico, pois nela se tem que conceber também os limites da cidadania. Tais limites são produzidos pelo capitalismo, “[...] sistema que não desenvolve a riqueza senão produzindo e reproduzindo o seu contrário, isto é, a miséria" (LÖWY, 1996, p. 1119). De acordo com Milton Santos (2008), é uma pobreza produzida politicamente pelas empresas e instituições globais,

[...] como é o caso do Banco Mundial, que, em diferentes partes do mundo, financia programas de atenção aos pobres, querendo passar a impressão de se interessar pelos desvalidos, quando, estruturalmente, é o grande produtor da pobreza. Atacam-se, funcionalmente, manifestações da pobreza, enquanto estruturalmente se cria a pobreza ao nível do mundo. E isso se dá com a colaboração passiva ou ativa dos governos nacionais (SANTOS, 2008, p. 73).

De acordo com Goiris (2010), a cultura do povo paraguaio sempre esteve fundamentada na sobrevivência. Trata-se de uma batalha de início remoto, contra a opressão e a exploração que se iniciou com a dominação espanhola e do próprio Vice-Reino do Rio da Prata. 
A família de Odenice vive também a expropriação cultural quando se refere ao idioma "guarani" (parte da cultura autóctone do Paraguai) que, aos poucos, vai sendo deixado de lado, principalmente pelas crianças, e ao uso do tererê com plantas medicinais, hábito cultural do povo guarani.

O uso diário e permanente de ervas medicinais é uma tradição que atravessa séculos. Não se trata de um processo sazonal ou de um modismo fitoterápico, como ocorre em outros países, mas, de uma memória antropológica que perpassa em forma atemporal todo o tecido social paraguaio. As ervas medicinais no Paraguai são ancestralmente classificadas em pohá ñaná e pohá roysá. As primeiras (pohá ñaná) se referem a ervas secas, colhidas e guardadas por longo tempo. As segundas (pohá roysá) são utilizadas diariamente em mate gelado sob a forma de folhas frescas (GOIRIS, 2010, p. 24):

É possível perceber ainda, no depoimento e nas inferências do marido de dona Odenice, que a fronteira, produto de um ato jurídico, produz a diferença cultural do mesmo modo que é produto desta. A fronteira também se constitui como espaço de perda da identidade.

O sujeito, previamente vivido como tendo uma identidade unificada e estável, está se tornando fragmentado; composto não de uma única, mas de várias identidades, algumas vezes contraditórias ou não resolvidas (HALL, 2006, p. 12).

Os limites mantêm-se vivos reproduzindo as diferenças. Compreender essa relação é, pois, da maior importância para desvendar os interesses que se escondem por trás dessa problemática. Quanto menos consciência o indivíduo tiver de sua condição na sociedade, maiores são as chances de ele ser manipulado, pois "[...] a cultura particular ou grupal é sistematicamente moldada e manipulada pelo Estado e/ou pelo mercado" (MARTINS, 2007, p. 51). Essa manipulação é vivida e sentida por Jair Premieri, um dos depoentes que auxiliam nesse processo de tentativa de olhar as fronteiras além dos seus limites.

Jair Premieri, 38 anos, mora em Santa Terezinha de Itaipu há quatro (2009). Trabalha como vigia no Frigorífico Municipal administrado por particulares e complementa a renda com coleta seletiva. O exercício de catadores envolve outros brasiguaios (não incluídos neste grupo de pesquisa). Conforme o senhor Jair Premieri:

Nasci em Toledo. Com cinco anos, em 1975, meu pai migrou para o Paraguai. A mãe abandonou o pai e levou a gente junto, ficamos 2 anos no Rio Grande do Sul (1977) e 3 em Santa Catarina (1980). Meu pai descobriu onde a gente estava e foi buscar a gente. E voltamos para Toledo. Estudei ali uns seis meses. Depois, retornamos para o Paraguai. [...] A gente se criou no pesado. [...]. Fiquei quase 30 anos, num lugar chamado Santa Maria. Passamos muita necessidade. O padrasto era carrasco. Uma vez quebrei uma porta de vidro porque queria comida. Depois, que quebrei daí passou até a fome pelo medo. Quando chegou em casa, meu padrasto não me bateu, mas, como castigo, me deixou mais tempo sem comer [...] Meu pai tinha terra no Paraguai, em 1974, a terra no Paraguai era barata. Era tudo mato. Era mais fácil. Nos últimos tempos, começou uma perseguição. Na saúde, se não tiver dinheiro é muito difícil para viver. [...] Para gente que tem esse nível de vida, aqui, no Brasil, pra nós é melhor. Eu, com problema de coluna. A pequena com hemorragia no nariz, a outra com problema no pulmão. Aqui, a saúde não é aquelas coisas. Mas é melhor que lá. [...] Se eu tivesse mais condições de trabalhar, a gente podia estar melhor. A 
gente trabalha com material reciclável também. Em 20 dias, não fiz nada, fiz 69 reais. As crianças com a bolsa família é uma roupinha, uns cadernos, às vezes na hora da necessidade até a luz, o gás. A mulher ajuda na reciclagem (PREMIERI, Depoimento Oral, jan. 2013).

Na década de 1970, quando a família de seu Jair (depoimento acima) se mudou para o Paraguai, foi assinado "[...] o tratado aprovado e promulgado no Brasil pelo Decreto Legislativo $\mathrm{n}$. 23, de 30 de maio de 1973, e pelo Decreto n. 72.707, de 28 de agosto de 1973, e no Paraguai pela Lei n. 389, de 11 de julho de 1973, e criava a empresa de Itaipu Binacional” (RIBEIRO, 2002, p. 25). O início da obra de construção da usina dá-se em 1978, sendo que o processo inicia em 1973 e termina em 1991. A Represa de Itaipu submergiu ampla parcela de terras agricultáveis do Extremo Oeste do Paraná.

Estima-se que esta Represa provocou a expropriação e a diáspora de aproximadamente quarenta e três mil pessoas, entre colonos, peões posseiros, arrendatários e índios guaranis, estes últimos localizados às margens do Rio Ocoí (ESTRELA, 2006, p. 458).

Os brasileiros que foram para o Paraguai com pouco ou nenhum recurso financeiro conseguiram tornar-se pequenos proprietários ou continuaram na condição de peão ou arrendatário, mas, hoje, estão retornando, sujeitando-se a determinadas condições de trabalho para poderem sobreviver, como é o caso daqueles na condição de catadores de resíduos recicláveis. Esse serviço é incentivado pela Empresa Itaipu Binacional para a manutenção do Lago de Itaipu, formado em 1982, que inclui, em seus programas, “[...] medidas para reaproveitar e reciclar material”, “[...] atividades [...] desenvolvidas com a ampla participação da comunidade: [...] e associações"15. Entre essas associações está a Associação dos Catadores e Catadoras de Resíduos Recicláveis de Santa Terezinha de Itaipu (ACARESTI), uma associação cuja finalidade é a coleta seletiva para reciclar resíduos sólidos. Segundo pesquisa ${ }^{16}$ realizada no ano de 2009, a ACARESTI é assessorada pela Prefeitura Municipal em sua estruturação e existência e incentivada pela Itaipu Binacional. Apresenta, em seu quadro de associados, um número significativo de brasiguaios.

Nesse contexto é que se percebe como a fronteira age na proteção do capital. Esses trabalhadores, os catadores, entre eles o senhor Jair e outros brasiguaios que têm filhos matriculados em escolas públicas do município, ao participarem da coleta seletiva, colocam-se a serviço da Itaipu Binacional, no entanto esta se exime de todo e qualquer compromisso com essa classe. São trabalhadores invisíveis para o sistema trabalhista e, como tal, excluídos de quaisquer direitos, a começar pelos contidos nas leis de trabalho, como décimo terceiro salário, fundo de garantia por tempo de serviço (FGTS), previdência social, férias e fỉns de semana remunerados. São trabalhadores considerados diferentes, que apresentam dificuldade para se adequarem a uma

\footnotetext{
${ }^{15}$ Disponível em: <http://www.itaipu.gov.br/meioambiente/politica-ambiental>. Acesso em: 16 jun. 2013.

${ }^{16}$ Momento em que a pesquisadora participava do Programa de Desenvolvimento Educacional (PDE) da Secretaria de Estado da Educação do Paraná.
} 
sociedade competitiva e aos quais, a cada dia, é negado o direito a ter direitos. Entende-se, nesse sentido, que, para o trabalhador, “[...] a fronteira nacional é só uma maneira de dividi-los para melhor os dominar [...]" (GONÇALVES, 1984, p. 102) e explorar, enquanto, para o capital, a fronteira é uma forma de proteção para a sua acumulação. Ao apoiar o catador e incentivar a sua participação na coleta seletiva, alugando prédio para o funcionamento da Associação e incentivando-o a associar-se, fornecendo cesta básica em momentos de crise, o Estado deixa de cumprir o seu papel junto ao cidadão para que seus direitos, como trabalhador, sejam garantidos. $\mathrm{O}$ Estado oculta a situação desse cidadão e auxilia no processo de acumulação do capital por empresas privadas.

Para Gonçalves (1984, p.157), “[...] a questão nacional e do Estado nacional é bastante complexa e devemos estar atentos para os interesses que por trás dela se escondem em cada caso concreto". O capital, segundo Marx, utiliza o que denomina “[...] 'constrangimento coercivo externo' que obriga o capitalista a crescer ou a desaparecer” (GONÇALVES, 1984, p. 102). Entenda-se, nessa análise, que, ao considerar o capital como 'sujeito', não se está colocando-o como o único determinante dos arrolamentos sociais, mas inserindo-o nos processos de afinidades que envolvem o espaço e o Estado em suas relações num processo de fronteira, ou seja, o papel que Estado e capital, em suas inclusões no espaço de fronteira, exercem pressões sobre os indivíduos, fazendo com que se movimentem para um lado e outro da fronteira nacional, na busca de possibilidades que os auxiliem a vencer os limites impostos à sua sobrevivência nesse espaço.

Dos depoimentos orais coletados, $100 \%$ dessas famílias passaram a fronteira do Brasil ao Paraguai no período de construção da hidroelétrica de Itaipu, momento em que coincide a atuação de governos militares entre os dois países, e estabelecem acordos entre ambos. É também um tempo em que ocorrem mudanças na lei de terras de um e de outro país. Observa-se que apenas $20 \%$, do total das famílias entrevistadas, mesmo morando no Brasil, ainda mantêm vínculo econômico com o Paraguai. Trata-se de um grupo minoritário que, mesmo com pouco capital, ainda assim, conseguiu adquirir terras paraguaias, conforme aponta Souchaud (2007):

[...] se instalan los migrantes del sur del Brasil (Río Grande do Sul y Santa Catarina). En su mayoría son de origen alemán, pero también italiano o eslavo. [...] Hoy dominan ampliamente la región Oriental no tanto debido a su superioridad numérica sino por a la imposición de un modelo cultural que se extiende desde las estructuras de producción y de comercialización al modo de vida modelando radicalmente el paisaje. Su éxito económico es hoy día ejemplar en el Paraguay, [...] Pese a su origen europeo muy marcado culturalmente, modificaron rápidamente las prácticas agrícolas importadas de Europa para adaptarlas a los esquemas sudamericanos de las zonas tropicales y subtropicales. Adquirieron las técnicas de un micro agricultura de subsistencia practicada sobre rosados y demostraron así una real capacidad de adaptación e innovación. [...] atravesaron la frontera con un capital, a veces pequeño, pero suficiente para la adquisición de tierra en Paraguay, entonces aproximadamente diez veces más barata. Paraguay les ofrecía amplias perspectivas (SOUCHAUD, 2007, p. 121-122). 
Assim, como relata Souchaud, também os prontuários dos filhos dos brasiguaios matriculados em escola pública brasileira em 2012, mostram o movimento dessa população na fronteira, os pais emigraram ainda crianças, principalmente dos Estados do Sul do Brasil (Rio Grande do Sul, Santa Catarina e Paraná, como mostra o registro de nascimento desses alunos brasiguaios, onde consta a naturalidade dos pais), estabelecendo-se em território paraguaio. $\mathrm{O}$ Quadro 1 elenca os locais de procedência, de nascimento ou de registro dos alunos brasiguaios.

Quadro 1 - Local de territorialização no Paraguai por familiares dos alunos brasiguaios

\begin{tabular}{l|l}
\multicolumn{1}{c|}{ LOCALIDADE - CIDADE } & \multicolumn{1}{c}{ DEPARTAMENTO } \\
\hline SANTA ROSA DEL MONDAY & ALTO PARANÁ \\
PRESIDENTE FRANCO & \\
SAN CRISTÓBAL & \\
MINGA GUAZU & \\
SANTA RITA & \\
LOS CEDRALES & \\
CIUDAD DEL LESTE & \\
SAN ALBERTO & \\
MBARACAYÚ & \\
COLÔNIA PADRE GUIDO & \\
HERNANDARIAS & \\
SANTO DOMINGO, SAN CRITÓBAL & \\
NARANJAL & \\
ENTRE LAGOS CIUDAD DEL LESTE & \\
IRUNHA & \\
SAN ALFREDO - NARANJAL & ITAPUA \\
\hline HOHENAU & \\
AURORA - SAN RAFAEL & \\
NARANJTO SAN RAFAEL & \\
OBLIGADO & \\
ENCARNACIÓN & CAAGUARAZÚ \\
\hline TUPERENDÁ & \\
RAÚL ARSENIO OVIEDO & \\
\hline TITO FIRPO & \\
\hline BELA VISTA & \\
\hline TAUGUÁ & \\
ASUNCIÓN & \\
LAMBARÉ & \\
GURAMBARÉ & \\
\hline LORETO & \\
\hline \multicolumn{1}{c}{ FOnte: Prontuários dos alunos } \\
\hline
\end{tabular}

As informações do Quadro 1 transpostas para a Representação 3, demonstram, a localização dos departamentos que constituem o território paraguaio, ocupados por brasiguaios que, em 2012, encontram-se matriculados em escolas brasileiras. 


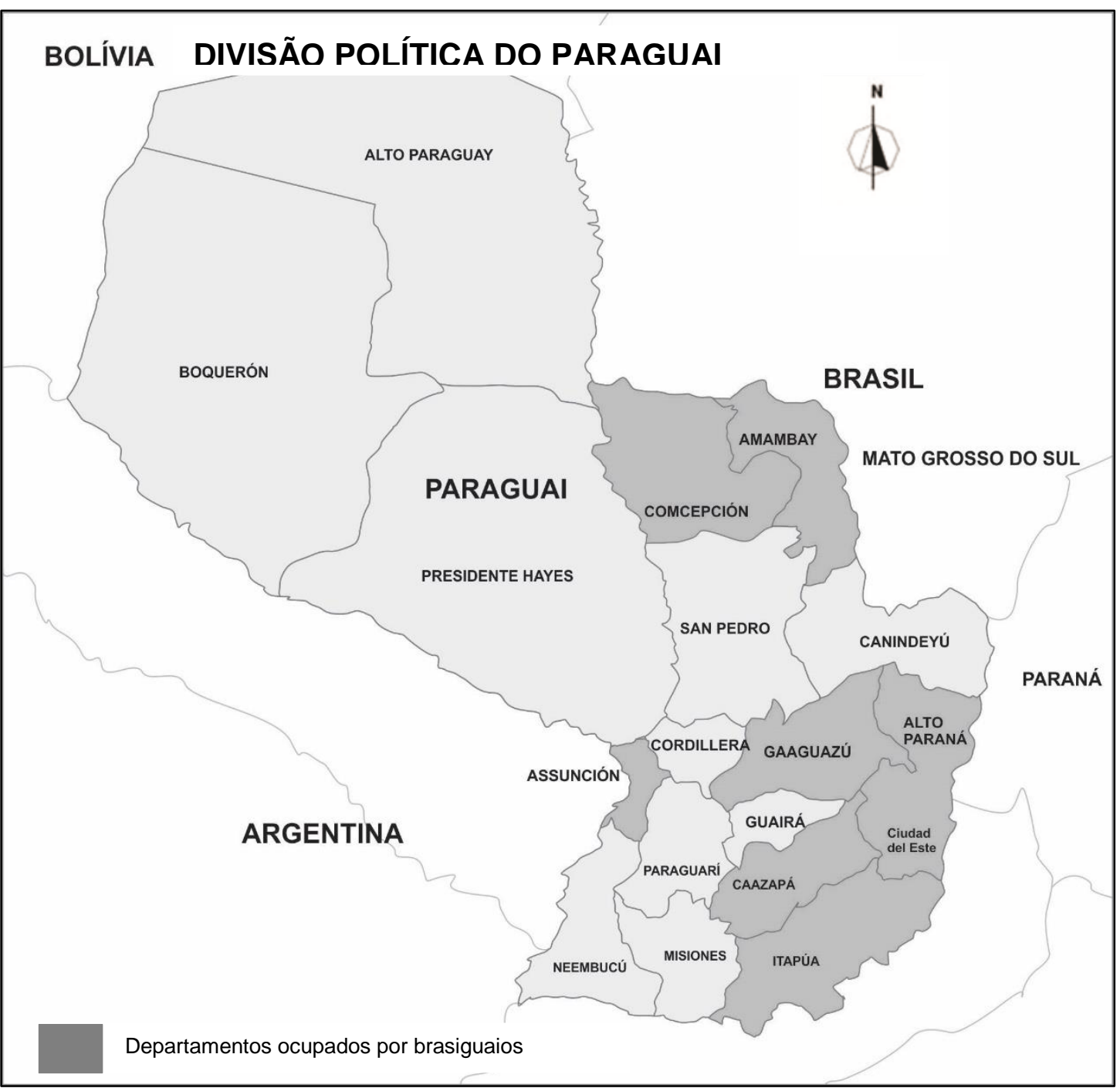

Representação 3 - Territorialização dos alunos brasiguaios no Paraguai quanto aos Departamentos no Paraguai Fonte: Prontuário dos alunos

Geografia_do_Paraguai ${ }^{17}$. Adaptado por Margarete Frasson, nov. 2013

Os Departamentos de Itapúa, Caazapá, Caaguazú fazem divisa com Alto Paraná. Isso significa que $80 \%$ das localidades encontram-se em Alto Paraná e em seu entorno, conforme mostra a Representação 3, com destaque aos Departamentos ocupados por brasileiros.

Apesar de o Paraguai, naquele momento, oferecer amplas perspectivas, os depoimentos orais mostram que $86 \%$ dessas famílias permaneceram naquele país de 30 a 38 anos. Considera-se que este espaço de tempo é o necessário para a agricultura passar da fase de subsistência para a comercial, pela análise do que ocorreu na região Oeste do Paraná. A agricultura tradicional passa para a agricultura moderna em período semelhante (1940 a 1971-75). Dessa forma, acredita-se tenha sido também o tempo necessário para que a modernização da agricultura se instalasse em terras paraguaias. O latifúndio incorpora a utilização química e mecânica em sua produção, expropriando o trabalho humano do campo, e tal expropriação pode ser observada no depoimento de Maria Aparecida dos Santos, 42 anos. Mora em Santa Terezinha de Itaipu há nove meses (2012):

\footnotetext{
${ }^{17}$ Disponível em: <http://pt.wikipedia.org/wiki/Geografia_do_Paraguai>. Acesso em: 3 nov. 2013.
} 
No Paraguai, a gente ia se virando. Trabalhando tanto para nós (trabalho na própria terra, três alqueires) como pros outros (diarista). [...] Meus filhos estudaram, aprenderam um pouco. Porque é mais difícil. Na roça, quando é o tempo do apuro, os filhos têm que ajudar. Era longe, quando chove, não dá para ir. Voltar para o Brasil, eu que decidi. Eu vi que não tinha vantagem ficar mais lá. Era muito difícil. Aqui, as coisas estão se encaminhando. No Paraguai, para quem tem é bom. Mas para quem não tem, que nem a gente, é muito difícil (SANTOS, Depoimento Oral, jan. 2013).

A família de dona Maria Aparecida dos Santos colocou à venda ${ }^{18}$ os três alqueires de terra no Paraguai para adquirir uma casa em Santa Terezinha de Itaipu. A terra era pouca, só seria possível sobreviver se houvesse saúde e trabalho em outras propriedades. Nesse sentido, a fronteira passa a ser, para os brasiguaios, um sujeito político, a face vivida da face agida do poder, uma vez que o poder político manifesta-se quando dona Maria Aparecida e sua família são desterritorializados do espaço em que viviam por não conseguirem mais sobreviver nele. São obrigados a tomarem uma decisão, migrar, na esperança de suprir, no mínimo, as necessidades básicas. Ficam claras, a partir dos depoimentos, duas evidências do capitalismo: (i) os latifúndios no Paraguai estão se expandindo e (ii) a produção de mercadorias desenvolve-se.

[...] aquilo que você mesmo poderia produzir (se tivesse os meios e condições) tem que comprar e assim a produção de mercadorias se desenvolve na medida em que se expropriam os trabalhadores das condições de sua autonomia [...] (GONÇALVES, 1984, p. 66).

De acordo com Mészáros (2011, p. 230): “os representantes das seções mais poderosas do capital compreendem que não estão em posição de dispensar a proteção oferecida por seus Estados nacionais aos seus interesses vitais". Assim, Brasil, Argentina, Uruguai e Paraguai, “[...] após décadas de desconfiança entre si, [...] conseguiram firmar em 1991 [...] um arranjo diplomático que desaguaria no Mercado Comum do Sul, Mercosul“ (LESSA; ARRAES, 2011, p. 3), que se inicia no final da década de 1980 (com o fim do governo militar), seguido da declaração de Iguaçu em 1985, sendo, em 1986, assinado o Programa de Integração e Cooperação Econômica (PICE). Em 1988 foi assinado o Tratado de Integração, Cooperação e Desenvolvimento e, em 1990, a Ata de Buenos Aires (FARIA; COUTINHO, 2011). Surgiu, como entidade jurídica de direito internacional, em 1991, por meio da assinatura do Tratado de Assunção (SILVA; RODRIGUES, 2011).

A convivência entre os países da região no Mercosul significou a delimitação de um posicionamento político-econômico na nova ordem mundial, caracterizada pelo espraiamento da democracia neoliberal, diferente de outros períodos históricos (LESSA E ARRAES, 2011, p. 3),

\footnotetext{
${ }^{18}$ Assim também foi com o seu Jair Premieri e com dona Odenice Dionísio da Conceição (depoentes desta pesquisa), cujo relato desse fato deu-se depois de encerrada a gravação.
} 
De acordo com Faria e Coutinho (2011), o Tratado de Assunção, nos primeiros anos, adotou, como preocupação fundamental, a liberalização comercial, porém, ao longo do processo, temas que foram contemplados na origem, contudo, sem grande destaque, foram ganhando importância, dentre eles as questões que influem no processo de integração regional social e democrática ${ }^{19}$, além das assimetrias ${ }^{20}$.

A participação dos dois países no mesmo Bloco Econômico, o Mercosul, prioriza as relações econômicas e a integração regional, no entanto, em seu cotidiano, as relações concretas estão acentuadamente marcadas por um processo histórico que leva "[...] a processos simultâneos e contraditórios de mistura cultural e de afirmação de identidades nacionais e preconceitos mútuos" (ALBUQUERQUE, 2010, p. 46), o que resulta, conforme os depoentes, em um processo de pressão nos últimos tempos sobre integrantes de outra nacionalidade, cujo reflexo atinge os que dispõem de menores recursos financeiros, o que os obriga a deslocar-se para os espaços fronteiriços.

Assim, a década de 1990 marca a Tríplice Fronteira com a criação do Bloco Econômico Mercosul, em 1991. Torna-se realidade internacional a partir de 1995, fato que influencia no movimento da fronteira pelas relações internacionais e altera as suas dimensões políticas, sociais e econômicas. As fronteiras entre nações assumem novas dimensões no contexto do bloco econômico, pois passam de segurança nacional à fronteira de integração regional. Nesse sentido, constituem-se como espaços de marcante intensidade, com movimentos peculiares, como no âmbito econômico, “[...] a livre circulação de bens, serviços e fatores produtivos" (TRATADO DE ASSUNÇÃO, 1991, Art. $1^{\circ}$ ). Trata-se de atividades que estão submetidas ao atrito entre regras e pressões políticas, o que levou à “[...] criação do Foro de Consulta e Concertação Política, composto pelos membros da chancelaria dos países, [...] o Protocolo de Olivos, que modifica o mecanismo de solução de controvérsias" (FARIA; COUTINHO, 2011, p. 19) e pressões socioeconômicas como a questão da “[...] redução das desigualdades entre os países membros, com o Fundo para Convergência Estrutural do MERCOSUL - FOCEM" (FARIA; COUTINHO, 2011, p. 20). Isso vem aumentando a circulação de bens e produtos na região e, com eles, o movimento populacional, fazendo com que trabalhadores morem no Brasil, mas tenham vínculo de trabalho com empresas do Paraguai e vice-versa.

\footnotetext{
${ }^{19}$ Resulta na suspensão do Paraguai do Mercosul, que, segundo a presidente Dilma Rousseff, foi definida em respeito à integração regional e à democracia. Dilma disse que a suspensão será mantida inalterada até 21 abril de 2013, quando ocorrem eleições presidenciais no país [...]. (Agência Brasil, on-line, 7 dez. 2012).

${ }^{20}$ No sistema internacional, o conceito aparece geralmente associado a conotações negativas, que se traduzem nos famosos diferenciais de poder político ou de poder econômico que separam os países do mundo. Essas assimetrias costumam dividir os países em um grupo restrito de nações poderosas - as superpotências -, um outro grupo intermediário de potências médias - que poderiam ser chamados de países emergentes, aqui, com diversas qualificações - e, finalmente, o resto, isto é, países menores e sem grande peso na comunidade internacional, em termos políticos, econômicos ou demográficos (ALMEIDA, 2005).
} 
A chegada de Fernando Lugo ao poder em 2008, no Paraguai, rompe com a hegemonia dos 61 anos de mandato do partido "Colorado". Ele assume uma política de apoio aos "campesinos paraguaios” com promessas de reforma social e agrária. Os “[...] ressentimentos da 'Guerra do Paraguai' afloram nos discursos dos camponeses paraguaios. Os brasileiros são então acusados de “invasores"” (ALBUQUERQUE, 2010, p. 240). Para o Paraguai, os resultados da guerra foram assombrosos.

Cerca de $60 \%$ da população do país morre. O Brasil e Argentina dividem entre si $40 \%$ do território paraguaio. A sociedade e economia agrícola ficam desestruturadas: quase $90 \%$ dos homens adultos morrem, e a população sobrevivente, de maioria feminina, fica dispersa e desorganizada (SOUCHAUD, 2011, p. 3).

Atualmente, “[...] o Paraguai tem uma classe dominante profundamente ligada ao setor agrário e descontente com a política adotada pelo então presidente Lugo" (Mario Sacchi ${ }^{21}$, Jornal Terra $)^{22}$. Dessa forma, segundo os depoentes desta pesquisa: "No Paraguai, para quem tem é bom. Mas para quem não tem, que nem a gente, é muito difícil” (SANTOS, Depoimento, jan. 2012). Em outras palavras, no Paraguai "só está bom para quem tem muito dinheiro" (PREMIERI, Depoimento Oral, jan. 2012) ou "no Paraguai, para quem não tem nada, não tem futuro mais" (SCHINWELSKI, Depoimento Oral, jan. 2012) ou, ainda, "teve uma época que era bom. [...] Aí, foi dificultando" (CONCEIÇÃO, Depoimento Oral, jan. 2012).

Compreende-se que, não bastasse a oposição política, existe uma herança deixada pelos antecessores de governo. O presidente Stroessner, no poder durante décadas desde meados do século XX, aprimorou os inúmeros aspectos da política e da economia que, atualmente, interferem na sociedade local e privilegiam uma minoria, a elite, que também detém o poder político. Devido a isso, percebe-se, pelos fragmentos dos depoentes, que eles, os brasiguaios, tomam a decisão de deslocar-se no espaço, mas desconhecem a imensa trama em que estão envolvidos pelo Estado e pelo mercado, os quais, pela ideologia simbólica, tornam-nos invisíveis e, assim sendo, provocam a invisibilidade de sua condição social, econômica, política e ideológica. Nessa condição, cultivam a esperança e expectativa de uma vida melhor, se não para eles, pelo menos para os filhos. São portadores de uma educação fundada em princípios e valores morais e religiosos. Eles assumem sozinhos e individualmente a sua própria sorte. Politicamente, desconhecem que poderiam unir-se aos demais brasiguaios e lutar por melhores condições de vida e por uma escola que pudesse atender às características culturais híbridas de seus filhos.

Quando o pequeno agricultor vende o seu pedaço de terra da qual depende para a sua subsistência, não o faz por vontade própria, e sim por causa de alguma forma de pressão; o faz carregado da esperança na busca de melhores condições de vida, que pode estar em outro território,

\footnotetext{
${ }^{21}$ Professor do Curso de Relações Internacionais da ESPM.

${ }^{22}$ Jornal on-line. Disponível em: <http://www.terra.com.br/portal/>. Acesso em: 26 jan. 2013.
} 
pois o "[...] mundo foi sempre um conjunto de possibilidades. Hoje, porém, tais possibilidades são todas interligadas e interdependentes" (SANTOS, 2008b, p. 35) e assim também os limites. Limites e possibilidades são duas forças contraditórias que impulsionam e movimentam a população no mundo. Observe-se, porém, que o que se apresenta, neste momento, como possibilidade para o ser humano desta geração pode ser o limite para a próxima geração. Quando indagados sobre os motivos que os fizeram retornar ao Brasil (Quadro 2), os depoentes apresentaram, entre as suas respostas, a necessidade de tratamento médico de algum membro da família (SANTOS; MOREIRA; SILVA; PREMIERI, Depoimento Oral, jan. 2012); o estudo para os filhos e opções de trabalho (VALÉRIO; HENZ; SCHINWELSKI, Depoimento Oral, jan. 2012); aposentadoria, saúde e estudo (CANDIA; SHWENDLER, Depoimento Oral, jan. 2012); tratamento de saúde e estudo dos filhos (BRAATZ, Depoimento Oral, jan. 2012). No Quadro 2 apresentam-se os motivos que, de acordo com os próprios brasiguaios, levaram-nos ao Paraguai e aqueles que, hoje, trazem-nos de volta.

Quadro 2 - Síntese dos motivos dos deslocamentos dos brasiguaios na fronteira

\begin{tabular}{l|l}
\multicolumn{2}{c}{ MOTIVOS DE MIGRAÇÃO PARA OS BRASIGUAIOS } \\
\multicolumn{1}{|c}{ Migração para o Paraguai } & \multicolumn{1}{c}{ Retorno ao Brasil } \\
\hline $\begin{array}{l}\text { Apropriar-se de um pedaço de terra } \\
\text { Qualidade das terras }\end{array}$ & Saúde \\
Melhorar de vida & Aposentadoria \\
& Trabalho com carteira assinada \\
& Estudo para os filhos \\
& Alto custo de vida no Paraguai \\
\hline
\end{tabular}

Fonte: Relato oral fornecido por brasiguaios

Organizado por Margarete Frasson, abr. 2013

A migração ao Brasil apresenta-se, então, como solução para suprir tais necessidades, que não eram atendidas no Paraguai ou, se eram, custavam caro, para quem faz parte de um grupo com baixo poder aquisitivo, caso desta parcela da população. Ademais, essa tentativa do suprimento das necessidades, no Brasil, comparece acompanhada pela busca da identidade, perdida quando migraram para Paraguai e, ao retornarem, esperam encontrar a mesma identidade que conheceram pelo relato de seus pais sobre como era a identidade brasileira, que já não encontram. Dessa forma (BAUMAN, 2005), estão total ou parcialmente 'deslocados', tendo alguma coisa a explicar, desculpar, esconder ou, pelo contrário, a ostentar corajosamente. Dessa maneira, observa-se que a ausência/presença concebe uma intensa ruptura no tecido social. De acordo com Sayad,

[...] não se deixa sua terra impunemente, pois o tempo age sobre todos os seus pares. Não se prescinde impunemente do grupo e de sua ação cotidianamente presente, [...] bem como de seus mecanismos de inserção social, mecanismos que são ao mesmo tempo prescritivos e normativos e, enfim, largamente performativos (SAYAD, 2000, p. 14).

Embora, em sua aparência (Quadro 2), os brasiguaios demonstrem como sendo iniciativa deles os deslocamentos no espaço, na verdade, os agentes que estão compondo esse jogo são o 
mercado e o Estado, utilizando-se de processos populacionais reguladores. A fronteira, a partir deles, revela-se como lugares específicos nos diferentes territórios. Locais de encontro entrecruzados de horizontalidades e verticalidades, distintas, como "corte", pois no momento em que as geograficidades vividas em um país atrapalham a inserção do sujeito no espaço, este cruza a fronteira e tenta territorializar-se em outra Nação e buscar a sua identidade; mas também aparecem como "costura", quando essas horizontalidades e verticalidades se entrecruzam nos dois lados da fronteira, fazendo desse espaço um único espaço, contraditório, carregado de complementaridades de um mesmo sistema social e econômico, o capitalismo, que atua nos dois lados da fronteira apoiado pelas ações políticas.

A fronteira para o capital é uma proteção, um mecanismo que se utiliza da própria fronteira para o processo de acumulação. A fronteira como fato, irá justificar e encobrir o processo de espoliação ao brasiguaio no contexto social.

A partir disso, percebe-se a fronteira, lugar único, diferente, com fronteiras étnicas, com destinos de historicidades desencontradas, de tempos que não fluem simultaneamente na mesma direção. Esse espaço, marcado pela dinâmica entre Brasil e Paraguai, ocorre por meio de sua base material e de sua base normativa, bases que trazem em si uma infinidade de determinações e de ações que vêm concentrando a riqueza nas mãos de alguns, deixando o trabalhador (camponês ${ }^{23}$ ) cada vez mais sem direção, no caso específico deste estudo, os brasiguaios.

A fronteira se forma para o brasiguaio ao constituir-se como fato (financeiro, político, jurídico, militar e diplomático), neste caso, a fronteira permite o movimento que ocorre por meio do fluxo de pessoas, capitais, bens e serviços, cujos limites são impostos pelo capital. Trata-se de limites estabelecidos por acordos e tratados entre países.

Ao possibilitar a sobrevivência do brasiguaio nas duas nações e permitir que viva dupla nacionalidade, a fronteira funciona como costura, contudo, quando ao sujeito é dada a dupla nacionalidade, mas sem direitos sociais de cidadania e vive como expatriado, a fronteira, para ele, apresenta-se também como corte. Para esse sujeito a fronteira cumpre as duas funções ao mesmo tempo.

\section{APONTAMENTOS FINAIS}

O espaço geográfico da Tríplice Fronteira formada pela área urbana entre as três cidades fronteiriças (Puerto Iguazú - AR, Ciudad del Este - PY e Foz do Iguaçu - BR), constitui-se de vários centros, porém não dispõe de um núcleo em comum. Assim, comparece a existência da

${ }^{23}$ Camponês é aqui entendido como aquele que conduz diretamente as atividades no campo e que se utiliza predominantemente de mão de obra familiar, pelas formas tradicionais de acesso à terra. Corresponde aos pequenos proprietários, aos arrendatários, aos agregados, aos rendeiros... 
fronteira, por não haver dependência entre esses três pontos. Cada cidade, particularmente, constitui-se em margem de outro espaço centrado no interior do Estado Nação (AR, PY, BR), sendo a ele subordinado. Inserida nessa estrutura encontra-se a cidade de Santa Terezinha de Itaipu. Há uma tentativa, por meio do Mercosul, de se edificar, nessa região, uma existência unitária, no entanto o que se tem é “[...] um mosaico de relações, de formas, funções e sentidos” (SANTOS, 2008a, p. 67).

$\mathrm{Na}$ área urbana dessa fronteira transitam migrantes de diferentes nacionalidades, como se estivessem circulando entre bairros de uma única cidade. Esse movimento social faz com que os três países se integrem num sistema próprio, típico dessa região fronteiriça. $\mathrm{O}$ movimento populacional constrói, no transcurso histórico, espaços diferentes na mesma configuração territorial. Esses espaços atendem às diferenças culturais desses grupos de migrantes (escolas, igrejas, comércio). Eles territorializam-se sem deixar de participarem da dinamicidade territorial dessa fronteira. Em seu limiar se localizam os que estão em luta contínua na busca por sobrevivência, nos diferentes lados das fronteiras nacionais entre Brasil e Paraguai, os brasiguaios. Esses migrantes encontram-se em constante espacialização, vivendo em territorialização precária. Na fronteira, esses sujeitos deparam-se com perspectivas de diferentes visões de mundo no conflito de historicidades desencontradas e na contradição do encontro e do desencontro entre línguas e culturas. Essa precariedade e essas diferentes direções fazem com que vivam no limite.

$\mathrm{Na}$ pesquisa verificou-se que os alunos brasiguaios pertencem a famílias que, há gerações, vivem num círculo vicioso de abandono pelo Estado e de exploração pelo sistema capitalista. A falta das condições de vida humana digna acompanha esses sujeitos. A dinâmica econômicojurídico-político-ideológica entre os Estados nacionais, por meio de sua base material e normativa, concentra a riqueza nas mãos de alguns. Isso faz com que o trabalhador, que traz com ele próprio a vivência em lidar com a terra para produzir seu sustento, fique cada vez mais sem destino. Essa situação os faz buscar a sobrevivência cotidiana nas duas nações (Brasil e Paraguai). Com dupla nacionalidade, vivem como expatriados nos dois países.

No contato direto com esses migrantes percebeu-se ${ }^{24}$ sua educação ser constituída por valores que conduzem a convivência social organizada, pacifíca harmoniosa. Há uma prática diária carregada de solidariedade viva presente em suas ações e relações.

Em função da dinâmica analisada, para esses migrantes a fronteira é uma "realidade social" que possui um passado histórico, é fruto de um processo de construção, desconstrução, reconstrução e reelaboração da vida, produzida a partir de relações humanas em sociedade que envolve ações

\footnotetext{
${ }^{24}$ Foram observações que ocorreram da seguinte forma: após a entrevista, as famílias onde se perceberam maiores necessidades econômicas, a elas se retornou levando roupas usadas, mas em bom estado de conservação. Quando abriam a sacola e viam as roupas já iam fazendo a distribuição entre os membros da própria família. No caso de roupas que não estavam no tamanho adequado para a família, já mencionavam pessoas que ainda moram no Paraguai e que, no primeiro contato com eles, iriam entregar.
} 
políticas, jurídicas, econômicas, ideológicas, de interações constantes que se estabelecem entre os indivíduos e deles com o meio pelas práticas cotidianas. O mundo social apresenta-se como natural, de uma geração a outra. Dessa maneira, o mundo passa a ser legitimado e reconhecido como certo, naturalizado, o que impede o sujeito de perceber-se como elemento que é utilizado pelo jogo do capital, este, atua por meio de forças do poder que não se vê, e estas, criam as formas que excluem o sujeito da sociedade.

\section{REFERÊNCIAS}

ALBUQUERQUE, José Lindomar C. A dinâmica das fronteiras: os brasiguaios na fronteira entre o Brasil e o Paraguai. São Paulo: Annablume, 2010.

ALMEIDA, Rosemeire Aparecida de. Identidade, distinção e territorialização: o processo de (re)criação camponesa no Mato Grosso Do Sul. 2003. Tese (Doutorado em Geografia) - Faculdade de Ciências e Tecnologia da Universidade Estadual Paulista - UNESP, Presidente Prudente, 2003.

AMARAL, Arthur Bernardes do. A Tríplice Fronteira e a guerra ao terror. Rio de Janeiro: Apicuri, 2010.

BÁRBARA, Marcelo Santa. Brasiguaio: territórios e jogos de identidade. In: PÓVOA NETO, Helion; FERREIRA, Ademir Pacelli (Org.). Cruzando fronteiras disciplinares. Rio de Janeiro: Revan, 2005.

BAUMAN, Zygmum. Identidade: entrevista a Benedetto Vecchi. Tradução Carlos Alberto Medeiros. Rio de Janeiro: Jorge Zahar, 2005.

CERTEAU, Michel de. A invenção do cotidiano: arte de fazer. Trad. Ephraim Ferreira Alves. 14. ed. Petrópolis, RJ: Vozes, 2008. p. 35-351.

COLODEL, José Augusto. Obrages \& Companhias Colonizadoras: Santa Helena na história do oeste paranaense até 1960. Santa Helena, PR: Prefeitura Municipal, 1988.

ESTRELA, Ely Souza. Vozes de Itaipu: o testemunho de uma expropriação. Imaginario, v. 12, n. 13, p. 457-459, 2006. Disponível em: <http://www.revistas.usp.br/ima/article/view/42436/46105>.

FARIA, Luiz Augusto Estrella; COUTINHO, Carolina Rigotti. Brasil e Argentina no Mercosul: uma análise da participação entre 2007 e 2010. Boletim Meridiano 47, v. 12, n. 125, p. 18-24, maio/jun. 2011.

FLEISCHFRESSER, Vanessa. Modernização tecnológica da agricultura. Curitiba, PR: Livraria do Chain: COCITEC:IPARDES, 1988.

FOUCAULT, Michel. Vigiar e punir: nascimento da prisão. Trad. Raquel Ramalhete. 40. ed. Petrópolis, RJ: Vozes, 2012.

GOIRIS, Fabio Anibal. O desconhecido como preceito: o caso do Paraguai. Revista Espaço Acadêmico, n. 112, p. 23-30, set. 2010. 
GONÇALVES, Carlos Walter Porto. Paixão da terra: ensaios críticos da ecologia e geografia. Rio de Janeiro: Pesquisadores Associados em Ciências Sociais, 1984.

GONÇALVES, Karoline Batista. A migração de brasileiros para a Colônia Nueva Esperanza em Yby Yaú no Paraguai e a formação de uma "Nova Identidade Territorial". Revista Percurso NEMO, Maringá, v. 3, n. 1, p. 3-13, 2011.

GREGORY, Valdir. Os euro-brasileiros e o espaço colonial: a dinâmica da colonização no Oeste do Paraná nas décadas de 1940 a 1970. Cascavel, PR: Edunioeste, 2008.

HAESBAERT, Rogério. O mito da desterritorialização: do "fim dos territórios" à multiterritorialidade. 5. ed. Rio de Janeiro: Bertrand Brasil, 2010.

HALL, Stuart. A identidade cultural na pós-modernidade. Trad. Tomaz Tadeu da Silva e Guacira Lopes Louro. 11. ed. Rio de Janeiro: DP\&A, 2006.

HARACENKO, Adélia Aparecida de Souza. O processo de transformação do território no noroeste do Paraná e a construção das novas territorialidades camponesas, 2007. 627 p. Tese (Doutorado em Geografia) - Universidade de São Paulo, Faculdade de Filosofia Letras e Ciências Humanas, São Paulo, 2007.

HISSA, C. E. V. A mobilidade das fronteiras: inserções da geografia na crise da modernidade. Belo Horizonte, MG: UFMG, 2006.

IPARDES. Fundação Édison Vieira. O Paraná reinventado: política e governo. Curitiba, 2006.

LESSA, Antônio Carlos; ARRAES, Virgílio Caixeta. Mercosul: a trajetória em formação. Boletim Meridiano 47, v. 12, n. 125, p. 18-24, maio/jun. 2011.

LÖWY, Michael. As aventuras de Karl Marx contra o Barão de Münchhausen: marxismo e positivismo na sociologia do conhecimento. 5. ed. São Paulo: Cortez, 1996.

MACCARI, Neiva Salete Kern. Migração e memórias: a colonização do Oeste Paranaense. 1999. Dissertação (Mestrado em História) - Universidade Federal do Paraná, Curitiba, 1999.

MAROTTI, Paulo Sergio; SANTOS, José Eduardo dos. Narrativas orais como subsídio para um programa de educação ambiental direcionado a uma unidade de conservação. In: SANTOS, José Eduardo dos; SATO, Michele. A contribuição da educação ambiental à esperança de Pandora. São Carlos, SP: Rima, 2001. p. 197-224.

MARQUES, Denise Helena França. Circularidade na fronteira do Paraguai e Brasil: o estudo de caso dos "brasiguaios". 2009. Tese (Doutorado em Demografia) - Universidade Federal de Minas Gerais, Faculdade de Ciências Econômicas, Belo Horizonte, 2009.

MARTINS, Estevão de Resende. Cultura e poder. São Paulo: Saraiva, 2007.

MEIHY, José Carlos Sebe Bom. Manual de história oral. São Paulo: Loyola. 1996.

MÉSZÁROS, István. Para além do capital: rumo a uma teoria da transição. Trad. Paulo Cezar Castanheira e Sérgio Lessa. São Paulo: Boitempo, 2011.

RAFFESTIN, Claude. Por uma geografia do poder. São Paulo: Khedir Ed., 2011. 
RIBEIRO, Maria de Fátima Bento. Memórias do concreto: vozes na construção de Itaipu. Cascavel,PR: Edunioeste, 2002.

RIBEIRO, Maria de Fátima Bento. Metamorfoses do espaço habitado: fundamentos teóricos e metodológicos da geografia. 6. ed. São Paulo: EDUSP, 2008a.

RIBEIRO, Maria de Fátima Bento. Por uma outra globalização: do pensamento único à consciência universal. 16. ed. Rio de Janeiro: Record, 2008b.

SAYAD, Abdelmalek. A Imigração. Tradução Cristina Murachco. São Paulo: Editora da Universidade de São Paulo, 1998.

SAQUET, Marcos Aurélio. Por uma geografia das territorialidades e das temporalidades: uma concepção multidimensional voltada para a cooperação e para o desenvolvimento territorial. São Paulo: Outras Expressões, 2011.

SILVA, André Luiz Reis da; RODRIGUES, Kamila Dalbem. Além das "assimetrias": a participação do Uruguai e do Paraguai no Mercosul. Boletim Meridiano 47, v. 12, n. 125, p. 25-31, maio/jun. 2011.

SOUCHAUD, Sylvain Geografía de la migración brasileña en Paraguay. Asunción: UNFPAADEPO, 2007.

SOUCHAUD, Sylvain A visão do Paraguai no Brasil. Contexto Int., v. 33, n. 1, p. 131-153, 2011. Disponível em: <http://www.scielo.br/pdf/cint/v33n1/v33n1a06.pdf〉.

SPRANDEL, Márcia Anita. Brasiguaios: conflito e identidade em fronteiras internacionais. 1992. Dissertação (Mestrado em Antropologia Social) - Universidade Federal do Rio de Janeiro, Rio de Janeiro, 1992.

THOMPSON, Paul. A voz do passado: história oral. Trad. Lólio Lourenço de Oliveira. 3. ed. Rio de Janeiro: Paz e Terra, 2002.

WESTPHALEN, Cecília et al. Nota prévia ao estudo de ocupação da terra no Paraná moderno. Boletim da Universidade Federal do Paraná, Curitiba, n. 7, p. 1-51, 1968.

ZAAR, Miriam Hermi. A produção do espaço agrário: da colonização à modernização agrícola e formação do Lago de Itaipu. Cascavel, PR: EdUnioeste, 1999.

\section{DEPOIMENTO ORAL}

BRAATZ, Nore. Depoimento concedido a Margarete Frasson. Santa Terezinha de Itaipu, jan. 2013.

CANDIA, Maria Edith Gamarra. Depoimento concedido a Margarete Frasson. Santa Terezinha de Itaipu, jan. 2013.

CONCEIÇÃO, Odenice Dionízio da. Depoimento concedido a Margarete Frasson. Santa Terezinha de Itaipu, jan. 2013. 
HENZ, Rosalina Aparecida. Depoimento concedido a Margarete Frasson. Santa Terezinha de Itaipu, jan. 2013.

MOREIRA, Iracema. Depoimento concedido a Margarete Frasson. Santa Terezinha de Itaipu, jan. 2013.

PREMIERI, Jair. Depoimento concedido a Margarete Frasson. Santa Terezinha de Itaipu, jan. 2013.

SANTOS, Maria Aparecida dos. Depoimento concedido a Margarete Frasson. Santa Terezinha de Itaipu, jan. 2013.

SCHINWELSKI, Marlice Inês Freitas. Depoimento concedido a Margarete Frasson. Santa Terezinha de Itaipu, jan. 2013.

SHWENDLER, Neiva Solane. Depoimento concedido a Margarete Frasson. Santa Terezinha de Itaipu, jan. 2013.

SILVA, Silvia Maura Januário da. Depoimento concedido a Margarete Frasson. Santa Terezinha de Itaipu, jan. 2013.

VALÉRIO, Márcia Ribeiro. Depoimento concedido a Margarete Frasson. Santa Terezinha de Itaipu, jan. 2013. 